\title{
The Differential Effects of College Experiences on Cognitive Outcomes Among First-Generation Subpopulations
}

\author{
Michael F. Iorio \\ Loma Linda University
}

Received: Nov. 3, $2019 \quad$ Accepted: Dec. 31, $2019 \quad$ Published: February 1, 2020

doi:10.5296/jse.v10i1.16198ＵRL: https://doi.org/10.5296/jse.v10i1.16198

\begin{abstract}
Study purpose was to evaluate how select college experiences affect cognitive outcomes among racial/ethnic populations of first-generation students. A nationwide dataset consisting of the 2006 The Freshman Survey (TFS) and the 2010 College Senior Survey (CSS) was utilized to address the research question. Findings from this study suggest that select college experiences positively affect cognitive outcomes, but the magnitudes of these effects vary for racial/ethnic subpopulations.
\end{abstract}

Keywords: first-generation, college experiences, predictors, cognitive skills, differences by race, college outcomes 


\section{Mll Macrothink}

Journal of Studies in Education

ISSN 2162-6952

2020, Vol. 10, No. 1

Higher education in the United States is flourishing with students from diverse backgrounds (Hussar \& Bailey, 2013; Snyder, de Brey, \& Dillow, 2019). This unparalleled expansion means that student success will continue being foundational to the mission of higher education, especially for historically underserved students. However, these underserved populations of students of color, students from low income families, and first-generation students continue to experience barriers related to their success in higher education in the United States (Chen, 2005; DeAngelo, Franke, Hurtado, Pryor, \& Tran, 2011; Ishitani, 2006; Musu-Gillette et al., 2016; National Center for Education Statistics, 2011; Snyder et al., 2019; Snyder \& Dillow, 2012).

One college success measure across institutions in the United States relates to cognitive outcomes (Association of American Colleges and Universities, 2007; Astin, 1973, 1993a, 1993b; Mayhew et al., 2016; Pascarella \& Terenzini, 1991, 2005; Pace, 1979). These college outcomes characterize not only essential critical thinking and problem solving skills, but also general knowledge and knowledge related specifically to academic disciplines. Among other college outcomes, a college education helps students to develop and refine cognitive outcomes, which demonstrate higher-order intellectual skills expected of college graduates.

The literature suggests that college environments contribute to cognitive outcomes (Bowman, 2009, 2013; Kim \& Sax, 2009; Nelson Laird, Seifert, Pascarella, Mayhew, \& Blaich, 2014; Pike et al., 2011; Shim \& Walczak, 2012). This seems to indicate college environments are important for college students in general, and specifically in the context of educational outcomes. However, effects of these experiences tend to differ for racial/ethnic populations (Edens et al., 2015; Kim et al., 2014; Flowers \& Pascarella, 2003; Kugelmass \& Ready, 2011), and for first-generation students (Filkins \& Doyle, 2002; Kim \& Sax, 2009; Padgett et al., 2012; Pascarella et al., 2004; Terenzini et al., 1996). Absent from the literature is how college experiences affect cognitive outcomes among first-generation racial/ethnic subpopulations. Therefore, while studies may shape the understanding about how college experiences affect cognitive outcomes, more studies in this area are needed to ascertain impact for first-generation subpopulations. The purpose of this study was to evaluate how select college experiences affect college outcomes among racial/ethnic populations of first-generation students.

\section{Literature Review}

\section{First-Generation Students}

Studies showing how educational levels of parents affect education outcomes of children are abundant (Billson \& Terry, 1982; Bowman, 2010; Haller \& Portes, 1973; Pascarella, Pierson, Wolniak, \& Terenzini, 2004; Terenzini, Springer, Yaeger, Pascarella, \& Nora, 1996). Correlating parental achievement and educational outcome of children provides insight about lower levels of persistence and attainment for students whose parents have limited or no college experience when compared to their counterparts whose parents have college experience (Chen, 2005; DeAngelo et al., 2011; Ishitani, 2006; National Center for Education Statistics, 2011; Snyder et al., 2019; Snyder \& Dillow, 2012). 


\section{MlMacrothink}

Journal of Studies in Education

ISSN 2162-6952

2020, Vol. 10, No. 1

Approximately one-third of college students have parents who have not participated in higher education (National Center for Education Statistics, 2014). Therefore, first-generation students represent a significant population across higher education institutions in the United States. Although this population is diverse in terms of race/ethnicity and gender, these students tend to be from lower income backgrounds, are more likely to have employment responsibilities, and are generally underprepared for college academics (ACT, 2014a, b; Blackwell \& Pinder, 2014; Bui, 2002; Coffman, 2011; Engle \& Tinto, 2008; National Center for Education Statistics, 2014; Saenz et al., 2007; Terenzini, et al., 1996).

The combination of lower family income and lower parental educational levels means that first-generation students have a lower socioeconomic status in the United States. Socioeconomic status is an important consideration in U. S. higher education because of the direct relationships between degree attainment and employment, and degree attainment and income (see Alsalam \& Rogers, 1990; Kena et al., 2016; Bureau of Labor Statistics, 2018). As degree attainment increases, so do opportunities for employment and opportunities to earn a higher income, and earning a higher income makes it easier to acquire wealth. Therefore, socioeconomic status can be understood as a measure of wealth, and evidence suggests that household wealth offers children advanced positions in society that positively affects college preparedness (ACT, 2015; College Board, 2016).

Further exacerbating obstructions in the pathways for success for first-generation students is the overall pattern that college students who identify with historically underserved racial/ethnic populations continue to experience obstacles to success in college. For example, students who identify as Black and those who identify as Hispanic demonstrate lower four- and six-year attainments rates than their counterparts who identify as Asian and those who identify as White (DeAngelo, Franke, Hurtado, Pryor, \& Tran, 2011). Moreover, while percentages of Asian students and White students who earn degrees within six years is 4 and 12 percentage points higher than average, respectively, percentages of Black students and Hispanic students who earn degrees within six years is 18 and 6 percentage points lower than average, respectively (Musu-Gillette et al., 2016).

\section{Cognitive Outcomes}

Cognitive outcomes are central to higher education because they signify the acquisition of knowledge and the development of complex and sophisticated intellectual skills universal to educational domains (Association of American Colleges and Universities, 2007; Astin 1973, 1993a; Mayhew et al., 2016; Pace, 1979; Pascarella \& Terenzini 1991, 2005). Cognitive outcomes in U.S. higher education have been measured in several key areas:

- General and discipline-specific knowledge (see Bowman, 2009, 2013; Edens et al., 2015; Kim et al., 2014, 2015; Kim \& Sax, 2009; Nelson Laird et al., 2014; Pike et al., 2011)

- Critical thinking (see Bowman, 2009, 2010; Edens et al., 2015; Giancarlo \& Facione, 2001; Flowers \& Pascarella, 2003; Kim et al., 2014, 2015; Kugelmass \& Ready, 2011;

Nelson Laird et al., 2014; Pike et al., 2011; Shim \& Walczak, 2012; Whitmire, 1996; Whitten \& Brahmasrene, 2011) 
- $\quad$ Problem-solving (see Bowman, 2009, 2010; Kugelmass \& Ready, 2011; Nelson Laird et al., 2014)

In this study, cognitive outcomes were measured by creating a factor scale that included these four areas (general and discipline-specific knowledge, critical thinking skills, and problem-solving skills).

Differences in cognitive outcomes across racial/ethnic populations. Limited research regarding patterns of cognitive outcomes across racial/ethnic subpopulations of college students exists. In these studies, White students tended to report cognitive gains greater than their counterparts from other racial/ethnic populations when surveyed at early points and then again at later points in time during the college years, although Latino students tended to make the greatest gains overall (Edens et al., 2015; Kim et al., 2014). Additional evidence suggests that White students make greater cognitive gains than their Black counterparts early in college (Flowers \& Pascarella, 2003), and greater gains than their counterparts from other racial/ethnic populations later in college (Kugelmass \& Ready, 2011).

Indirect and direct measures of cognitive outcomes are important considerations because in some cases, students from different racial/ethnic populations tend to assess gains differently than objective measures of these gains. For example, Asian students and their Hispanic counterparts reported (indirect measure) cognitive outcome scores that aligned more closely with objective scores of these outcomes when compared to their White counterparts (Bowman, 2010). Bowman also suggested that Black students are less likely to report (indirect measure) scores of cognitive outcomes that align to their objective scores of cognitive outcomes than their White counterparts. Another consideration regarding indirect measures is the reporting tendencies of racial/ethnic populations. Asian students, for example, are less likely to report scores toward the extreme ends of a scale (Wang et al., 2008), which means that scores on indirect measures may be influenced by reporting tendencies, rather than by the measure itself.

\section{College Experiences as Predictors of Cognitive Outcomes for First-Generation Students}

Although limited research is available about the effects of college experiences on cognitive outcomes for first-generation students, there is evidence suggesting that experiences in college affect cognitive outcomes. These experiences are the results of interacting with college environments, and range from attending more highly selective institutions to participating in extracurricular activities.

First-generation students who attend highly selective institutions tend to benefit more in terms of cognitive outcomes than their peers whose parents have college experience (Pascarella et al., 2004). It is possible that highly selective institutions offer first-generation students the opportunity to make a greater investment in their educational experiences. Greater investments in educational experiences are particularly important for refining cognitive outcomes for first-generation students. This benefit has been shown for activities that require academic challenge, high expectations, and increased effort, especially in terms of hours studying, writing reports, and reading books (Padgett et al., 2012; Pascarella et al., 


\section{Macrothink}

Journal of Studies in Education

ISSN 2162-6952

2020, Vol. 10, No. 1

2004; Terenzini et al., 1996). This benefit has also been shown when these students complete more units, courses in general, courses in specific majors (e.g., arts, humanities, and sciences), and in cumulative GPA (Pascarella et al., 2004; Terenzini et al., 1996). However, the opposite pattern is evident for technical/professional-oriented courses where an increase in number of courses completed correlated to a decrease in cognitive outcomes for first-generation students (Pascarella et al., 2004).

Interacting with faculty also positively affects cognitive outcomes for first-generation students. This benefit is particularly valuable for research-oriented experiences with faculty (Kim \& Sax, 2009). Interacting with students shows a similar benefit related to cognitive outcomes, especially when these interactions are with peers who identify with diverse backgrounds (Filkins \& Doyle, 2002; Padgett et al., 2012; Pascarella et al., 2004). Conceivably, these types of interactions help first-generation students to create systems of academic and social support that contribute to positive cognitive outcomes (Filkins \& Doyle, 2002).

Participating in extracurricular activities such as campus union and clubs, athletics, and recreational facilities have positive effects on cognitive outcomes for first-generation students (Pascarella et al., 2004). However, other types of extracurricular activities such as employment (paid or volunteer) negatively affect cognitive outcomes for first-generation students (Pascarella et al., 2004) despite previous research which suggested that the amount of time working off campus did not affect cognitive outcomes (Terenzini et al., 1996). In contrast to employment activities, socially oriented activities are potentially more beneficial because they create opportunities for first-generation students to develop systems of support in college, which positively affect cognitive outcomes (Filkins \& Doyle, 2002).

\section{Conceptual Framework}

Astin's (1970) input-environment-output (I-E-O) model of college impact and Astin's (1984) student involvement theory formed the conceptual framework that guided this study. These two models, viewed in conjunction, provide a lens through which to view how college experiences affect college outcomes.

The I-E-O model shows how characteristics students bring with them to college (I), and attributes of college environments (E), affect college outcomes (O). These relationships help aid in understanding that student background characteristics influence college environments and outcomes, and that college environments affect college outcomes. These are what Astin (1970) described as main effects. Astin (1970) also described interaction effects across the I-E-O model where background characteristics influence college outcomes differently in different college environments, and where college environments influence college outcomes differently for different types of students. These effects are of primary concern in the current study as these effects provide insight about the effect or impact of college on cognitive outcomes.

Astin's (1984) student involvement theory was the second component of the conceptual framework, which guided this study. Involvement in this context is a measure of time, but 
also a measure of investment in terms of a quality and quantity of energy both physical and psychological in an activity. Moreover, involvement theory also assists in understanding the nature of involvement being variable for different students and being variable for different activities at different times. The variable nature of involvement means that some students will invest more time engaging activities than others, and that the same students will spend different amounts of time engaging in different activities. Involvement in this context is the primary concern in the study because this understanding provides insight about how the investment of time relative to specific college experiences affects cognitive outcomes.

\section{Methods}

The purpose of the current study was to evaluate how select college experiences affect college outcomes among racial/ethnic populations of first-generation students. This study utilized quantitative research methods to analyze a secondary dataset.

\section{Data Source and Sample}

The 2006 administration of the TFS and the 2010 administration of the CSS served as the data source for the current study. This nationwide and longitudinal dataset included responses from 13,973 college students enrolled across approximately 100 four-year institutions in the United States. These surveys are components of the Cooperative Institutional Research Program (CIRP) located at the Higher Education Research Institute (HERI) at the University of California Los Angeles (UCLA).

Self-reported data sources such as those utilized for the current study are considered valid when these instruments satisfy specific conditions. According to Kuh et al. (2001) and Umbach \& Kuh (2006), these five condition are:

1. The information requested is known to the respondents.

2. The questions are phrased clearly and unambiguously.

3. The questions refer to recent activities.

4. The respondents think the questions merit a serious and thoughtful response.

5. Answering the questions does not threaten, embarrass, or violate the privacy of the respondent or encourage the respondent to respond in socially desirable ways.

Additionally, in terms of measuring cognitive outcomes, Astin (1993b) suggested that self-reported data from students responding in retrospect over two points in time (i.e., freshman and senior years) is a viable option.

The analytical sample of first-generation students in the current study consisted of 1648 cases. In order to attain a sample more representative of the nationwide proportions of first-generation subpopulations (see National Center for Education Statistics, 2014), a weighing factor was applied to this sample. The results of the weighted sample for the multiple regression analysis included 1561 cases: Asian $(n=98)$, Black $(n=307)$, Hispanic $(n=352)$, and White $(n=804)$. 


\section{Variables}

A cognitive outcomes factor scale $(\alpha=.80)$ was created to function as the dependent variable. This scale considered knowledge (general and discipline specific), and critical thinking and problem-solving skills variables from the CSS. For these four variables, students measured their change from the freshman to the senior year.

Independent and control variables included first-generation status (i.e., students whose parents had no college experience), SAT composite score (SAT or corresponding ACT score), sex, race/ethnicity, and institutional selectivity. College experience variables included an academic engagement scale $(\alpha=.71)$ created by the researcher, four CIRP constructs (student-faculty interactions, pluralistic orientation, sense of belonging, and habits of mind), and hours per week studying/homework. Scales assessing frequencies of involvement were used to measure these six college experience variables.

\section{Analysis}

The dataset was screened and cleaned based on recommendations by Mertler and Vannatta (2010) and Tabachnick and Fidell (2013), and statistical analyses were conducted utilizing IBM SPSS Statistics version 24.0. ANCOVA analysis was performed to determine if cognitive outcomes differ for racial/ethnic first-generation students when the effects of HSGPA are controlled-HSGPA has been correlated to cognitive outcomes (DeAngelo et al., 2011; Fischer, 2007). Subsequently, an initial regression analysis was performed on the aggregate first-generation sample to identify significant college experience variables, while controlling for the effects of background characteristics and college environments. Finally, nonsignificant variables were removed from the multiple regression analysis, which reduced the final regression models to nine independent variables. Separate hierarchical multiple regression analysis disaggregated by race/ethnicity were then performed with the enter method. These separate regression analyses by race/ethnicity employed input and environmental variables in the first two blocks, respectively, and the six college experience variables in the final block. These analyses were conducted to identify variables that predicted cognitive outcomes, while controlling for the effects of background characteristics and college environments.

\section{Results}

\section{Self-Reported Cognitive Outcomes}

ANCOVA analysis revealed a significant difference in cognitive outcomes among four racial/ethnic subpopulations of first-generation students, $F(3,1643)=2.82, p=.038$, partial $\operatorname{eta}^{2}=.01$. Table 1 shows the follow-up pairwise comparisons indicating that Hispanic students reported significantly higher cognitive outcomes than Asian and White students, and Black students reported significantly higher outcomes than Asian students. Table 1 also shows the average reported cognitive outcomes scores across each of the four racial/ethnic subpopulations when the effects of HSGPA are considered equal. Although all four groups reported positive and somewhat similar cognitive outcome scores, Hispanic students reported making the greatest gains, while Asian students reported making the smallest gains. 


\section{Ml Macrothink}

Journal of Studies in Education

ISSN 2162-6952 2020, Vol. 10, No. 1

Moreover, the difference in scores reported by Black and by Hispanic students (.1 point) and by Asian and by White students (.26 points) are similar, while the largest score difference was between Asian and Hispanic students (.55 points).

Table 1

Pairwise Comparisons and Adjusted Race/Ethnicity Means and Variability Using HSGPA as a Covariate

Dependent Variable: Cognitive Outcomes

\begin{tabular}{|c|c|c|c|c|c|c|c|}
\hline \multirow{3}{*}{ Race (I) } & \multirow{3}{*}{ Race (J) } & \multirow{3}{*}{ Mean Difference (I-J) } & \multirow{3}{*}{ Std. Error } & \multirow{2}{*}{\multicolumn{2}{|c|}{ Difference $^{\mathrm{a}}$}} & \multirow{2}{*}{\multicolumn{2}{|c|}{$\underline{\text { Adjusted Means }}$}} \\
\hline & & & & & & & \\
\hline & & & & Lower Bound & Upper Bound & $M$ & $S E$ \\
\hline \multirow[t]{3}{*}{ Asian } & Black & $-.538^{*}$ & .263 & -1.053 & -.023 & 14.67 & .17 \\
\hline & Hispanic & $-.548^{*}$ & .215 & -.970 & -.126 & & \\
\hline & White & -.257 & .176 & -.602 & .089 & & \\
\hline \multirow[t]{3}{*}{ Black } & Asian & $.538^{*}$ & .263 & .023 & 1.053 & 15.21 & .20 \\
\hline & Hispanic & -.010 & .240 & -.481 & .462 & & \\
\hline & White & .282 & .209 & -.128 & .691 & & \\
\hline \multirow[t]{3}{*}{ Hispanic } & Asian & $.548^{*}$ & .215 & .126 & .970 & 15.22 & .13 \\
\hline & Black & .010 & .240 & -.462 & .481 & & \\
\hline & White & $.291^{*}$ & .145 & .007 & .575 & & \\
\hline \multirow[t]{3}{*}{ White } & Asian & .257 & .176 & -.089 & .602 & 14.93 & .06 \\
\hline & Black & -.282 & .209 & -.691 & .128 & & \\
\hline & Hispanic & $-.291^{*}$ & .145 & -.575 & -.007 & & \\
\hline
\end{tabular}

$* p<.05$

a. Adjustment for multiple comparisons: Least Significant Difference (equivalent to no adjustments).

Notes: Sample sizes varied by groups: Asian $(\mathrm{n}=131)$, Black $(\mathrm{n}=92)$, Hispanic $(\mathrm{n}=207)$, and White $(\mathrm{n}=1218)$

Based on estimated marginal means

\section{Effects of College Experiences on Cognitive Outcomes}

Table 2 presents the results of the hierarchical multiple regression analysis on cognitive outcomes. This model explained $17 \%$ of cognitive outcomes for Black and White students, $19 \%$ of cognitive outcomes for Hispanic students, and $21 \%$ of cognitive outcomes for Asian students. Moreover, whereas block three was significant for all four populations, block two was significant only for Black students. This table also shows limited effects of input and environmental variables across four populations, although these findings are beyond the scope of the current study. For example, identifying as male was a significant input variable for Asian students, and institutional selectivity was a significant environmental variable for Black students. Different patterns emerged for statistically significant college experiences where all four populations experienced varying effects.

Academic engagement. Being academically engaged predicted cognitive outcomes for all racial/ethnic subpopulations of first-generation students except for Asian students. Compared to Hispanic and White peers, the effects of academic engagement are nearly twice as strong for Black students. 


\section{Macrothink}

Sense of belonging. Feeling a sense of connectedness and importance on campus predicted cognitive outcomes for all racial/ethnic subpopulations of first-generation students except for Asian students. Compared to Black and Hispanic peers, the effects of sense of belonging are slightly stronger for White students.

Student-faculty interactions. Quality interactions with faculty predicted cognitive outcomes for Asian and White students. Effects of faculty interactions for Asian students are three times as strong when compared to White peers.

Habits of mind. Habits associated with success in higher education predicted cognitive outcomes for Hispanic and for White students, and is nearly twice as strong for Hispanic students when compared to their White peers.

Hours per week studying/homework. Investing more time studying and completing homework predicted cognitive outcomes for White students only.

Pluralistic orientation. Interacting with peers from diverse backgrounds predicted cognitive outcomes for Hispanic students only.

Table 2. Standardized and Unstandardized Regression Coefficients for Cognitive Outcomes across Racial/Ethnic Subgroups

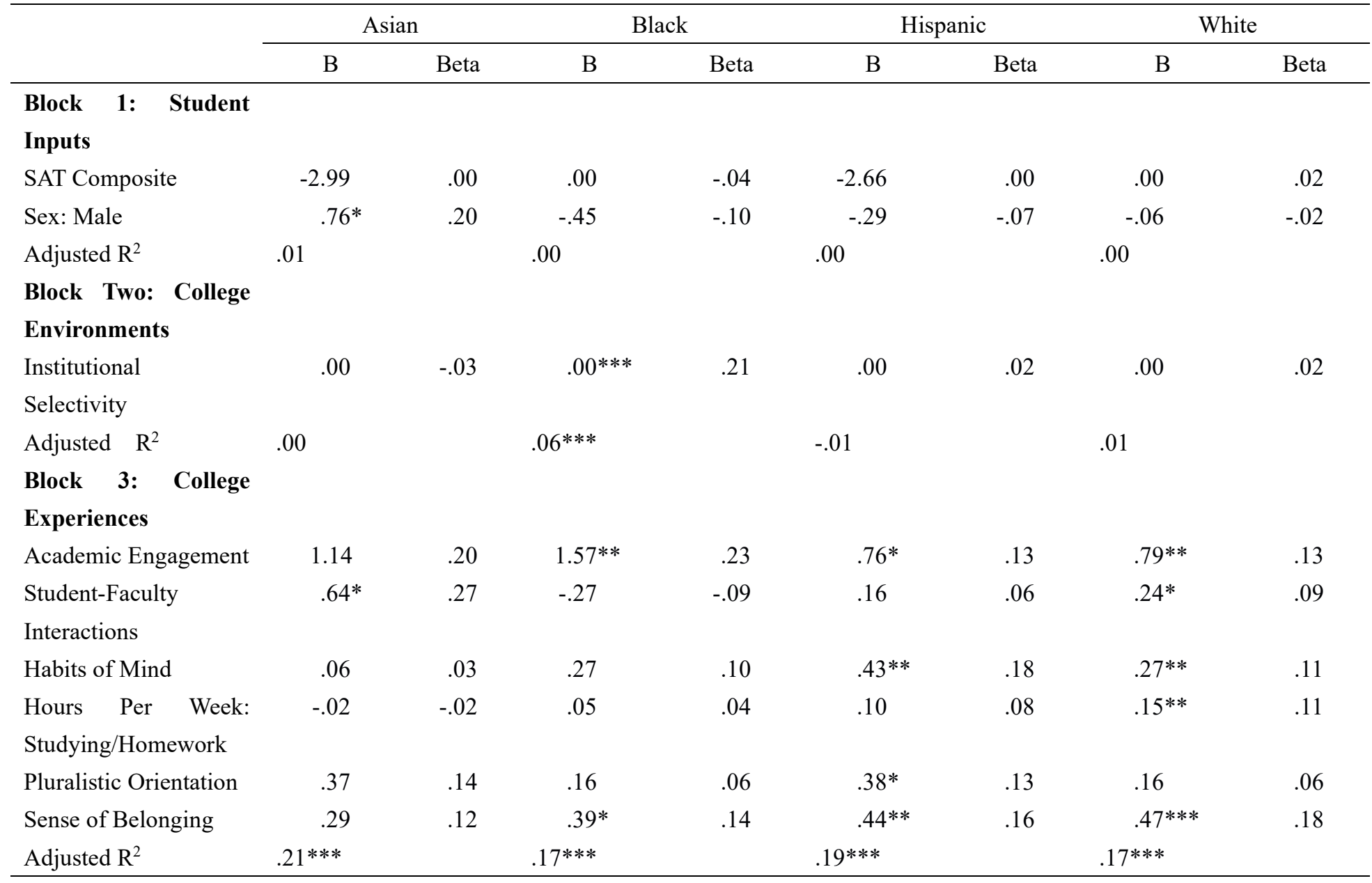

Notes: Weighted sample sizes varied by groups: Asian $(\mathrm{n}=98)$, Black $(\mathrm{n}=307)$, Hispanic $(\mathrm{n}=352)$, and White $(\mathrm{n}=804)$ 
${ }^{*} p<.05 ; * * p<.01 ; * * * p<.001$

\section{Limitations}

Although findings from the current study contribute to the literature several limitations present. Researchers tend to operationalize first-generation status as parents with no college experience or as parents not earning a bachelor's degree. In the current study, first-generation was operationalized as present with no college experience. Therefore, study findings may not be generalized to populations of first-generation students whose parents may have college experience, but who have not earned the equivalent of a bachelor's degree. Additionally, income was not employed as a variable in final models. As a result, first-generation students in the current study could be from low-, middle-, or high-income backgrounds, which may imply that some students have been better prepared for college academics than others.

Cognitive outcomes is a self-reported variable, which means that it is an indirect measure. Consequently, study findings may not be generalizable when direct measures of cognitive outcomes are incorporated. Although evidence supports the methodological validity of indirect and direct measures (Bowman, 2010; Bowman \& Seifert, 2011; Douglass et al., 2012; Gonyea, 2005; Kuh et al., 2001; Pace, 1985; Pike, 1996; Umbach \& Kuh, 2006), discussion about equivalency of indirect and direct measures for college outcomes is likely to be beneficial in determining validity.

Concerning the limitations inherent in self-reported data, another limitation relates to how participants scored responses. One scoring limitation is the potential for what Thorndike (1920) described as the halo error (i.e., responses that might influence other responses). A second scoring limitation is the tendency for some students, especially Asian students, to report scores closer to midline rather than toward extreme ranges (Wang et al., 2008). Collectively, these two scoring limitations mean that study findings based on self-reported data may not be generalizable to studies that used direct measures of cognitive outcomes.

A final limitation is a disproportionate number of cases by race/ethnicity, and that the current study did not consider racial/ethnic populations other than Asian, Black, Hispanic, and White. Therefore, study findings may apply only to these four subpopulations.

\section{Discussion}

Study findings are consistent with existing research suggesting that Black and Hispanic students report greater cognitive outcomes than Asian and White peers (Douglass et al., 2012; Edens et al., 2015; Kim et al., 2014). This similarity suggests that self-reporting cognitive outcomes is similar for students regardless of generation status. Potentially, Black students make greater gains in college because they tend to be underprepared for college level academics (ACT, 2016, 2017; Grodsky, Warren, \& Felts, 2008; Nord, 2011), and therefore college environments affect cognitive outcomes in disparate amounts. Another explanation could be an enhanced sense of determination (Solorzano, Ceja, \& Yosso, 2000), especially in 
light of the increased propensity to encounter pernicious discrimination, inequality, and racism in college (Aronson \& Inzlicht, 2004; Nelson Laird, 2005; Roska et al., 2017; Steele \& Aronson, 1995).

For Hispanic students, more pronounced outcomes in college might also result from fewer opportunities for development and refinement of these outcomes in high school (ACT, 2016, 2017; Nord, 2011). Likewise another possibility is that like their Black peers, Hispanic students are also resilient in the face of a negative racial climate in college (Hernandez, 2000; Prospero, Russell, \& Vohra-Gupta, 2012; Robertson, Bravo, \& Chaney, 2016; Yosso, Smith, Ceja, \& Solorzano, 2009).

Study findings are consistent with existing research suggesting that Asian and White students report less cognitive outcomes than Black and Hispanic peers (Douglass et al., 2012; Edens et al., 2015; Kim et al., 2014). These two populations may make fewer gains in cognitive outcomes in college because of better preparedness for college academics (ACT, 2016; 2017; Nord et al., 2011; Roska \& Arum, 2015). Another possible explanation could relate to the higher likelihood for Asian and for White students to pursue academic disciplines in STEM fields where grades are inherently lower (Chen, 2013; National Center for Education Statistics, 2014).

\section{College Experiences as Predictors for Racial/Ethnic Subpopulations}

The literature suggests that the college experiences that affect cognitive outcomes will vary for racial/ethnic populations of first-generation students, the findings from the current study offers supporting evidence. Whereas five college experiences predicted cognitive outcomes for White students, only four experiences, two experiences, and one experience had the same effects for Hispanic, Black, and Asian students, respectively. This variation suggests that different college experiences may affect racial/ethnic subpopulations of first-generation students differently. Furthermore, these experiences varied by magnitude, which means the same experiences may have different effects across racial/ethnic subpopulations of first-generation students. Disproportionate benefit for White students could be related to the influence on systems and processes White students and White faculty members have in college ranks. White students continue to be overrepresented in college student ranks, and White professors continue to be over represented in college faculty ranks (Mcfarland et al., 2017; Park, 2013; Snyder, de Brey, \& Dillow, 2019).

Being academically engaged is central to developing and refining cognitive outcomes for first-generation students (Filkins \& Doyle, 2002; Padgett et al., 2012; Pascarella et al., 2004; Terenzini et al., 1996). Study findings support the importance of this college experience, and suggest this type of engagement is important for Black, Hispanic, and White students. Perhaps, academic engagement might be an important and universal college experience for first-generation students; particularly for first-generation student who identify as Black. Conceivably, the classroom is central for this population because it provides an environment where students experience a sense of freedom to participate in academic experiences and overcome pernicious discrimination, inequality, and racism these students encounter in college. 


\section{Mll Macrothink}

Journal of Studies in Education

ISSN 2162-6952

2020, Vol. 10, No. 1

A sense of connectedness to campus is central to the college experience and to developing and refining cognitive outcomes for first-generation students (Filkins \& Doyle, 2002). The current study supports the importance of this college experience, and suggests that this connectedness is of similar importance for Black, Hispanic, and White students. Similar to academic engagement, perhaps sense of belonging might also be considered an important and universal college experience for first-generation students.

Quality interactions with faculty are central to the college experience and to developing and refining cognitive outcomes for first-generation students (Filkins \& Doyle, 2002; Kim \& Sax, 2009), though of less importance than academic engagement and sense of community. However, these interactions appear to be especially important for Asian first-generation students. Evidence suggests Asian students in general tend to benefit more from quality faculty interactions than their counterparts (Kim \& Sax, 2007, 2009; Lundberg \& Schreiner, 2004), and the current study suggests that this pattern also applies to Asian first-generation students. Perhaps, these interactions are particularly important for Asian first-generation students because of the influence of their parents who are familiar with the Eastern educational contexts where faculty members are viewed as essential to the learning process (Watkins, 2000).

Attitudes and behaviors as habits that support college success are central to the college experience and to developing and refining cognitive outcomes for first-generation students (Filkins \& Doyle, 2002; Kim \& Sax, 2009; Padgett et al., 2012; Pascarella et al., 2004). Although this college experience was not universally beneficial across each subpopulation, these experiences appear to be especially important for Hispanic first-generation students. Hispanic first-generation college students tend to be intrinsically motivated (Prospero et al., 2012), which enables them to frame challenges as opportunities, and to seek ways to maximize their learning in college.

Investing time in study and homework is central to developing and refining cognitive outcomes for first-generation students (Pascarella et al., 2004; Terenzini et al., 1996). Although this college experience was not universally beneficial across each subpopulation, these college experiences are especially important for White students in the current study. Although White students tend to be better prepared for college academics than their peers (ACT, 2016; 2017; Nord et al., 2011; Roska \& Arum, 2015), college academics appear to require a different investment of time for these students. Additionally, White students tend to have less familial responsibilities in college. Family obligations negatively affect college outcomes (Noll, Reichlin, \& Gault, 2017). Therefore, this population may spend more time studying, and consequently, receive more optimal gains in cognitive outcomes.

Pluralism is central to the college experience and to developing and refining cognitive outcomes for college students (Bowman, 2009; 2013; Hurtado, 2005; Hurtado, Mayhew, \& Engberg, 2012). Although this college experience was not universally beneficial across each subpopulation, study findings suggest this college experience is especially important for Hispanic students. Prior studies indicated Hispanic students emphasize the role people play in their college experience (Hernandez, 2000; Lundberg et al., 2007), so potentially Hispanic 
first-generation students invest more time interacting with people from diverse backgrounds, and consequently, receive more optimal gains in cognitive outcomes from such interactions.

\section{Implications}

\section{Theoretical Implications}

From a theoretical perspective, the findings from the current study suggest that cognitive outcomes are developmental, which supports theories of cognitive development based on studies of college students (see Baxter Magolda, 1992; Belenky et al., 1997; Kitchener \& King, 1981; Perry, 1999). A developmental perspective suggests growth in cognitive outcomes may occur in discernable stages (Kitchener \& King, 1981; Piaget 1967), or in logical/hierarchical progression (see Baxter Magolda, 1992; Belenky et al., 1997; Perry, 1999). Although the current study was not designed to assess these types of development, it revealed a progression in cognitive outcomes occurred over the course of the college years, and that this progression was influenced by college experiences.

Moreover, the findings from the current study also offer support to models of college impact that show how college environments and experiences affect college outcomes, and how these outcomes are influenced by student input characteristics, especially generation status (see Astin, 1970; Pascarella \& Terenzini, 1991, 2005; Tinto, 1993). Higher education remains salient in improving knowledge acquisition and thinking patterns of students.

Furthermore, study findings support Astin's (1984) theory of student involvement where investment of time and energy affects educational outcomes. Study findings provided insight about how this theory applies to first-generation college students. The college experience variables in the current study measured a frequency of investment in each activity, and with few exceptions, greater involvement contributed to greater cognitive gains.

\section{Practical Implications}

From a practical perspective, study findings suggest college experiences contribute to cognitive outcomes, but to different degrees for racial/ethnic subpopulations of first-generation college students. With this knowledge, higher education practitioners could create opportunities around these experiences for first-generation college students, while mentoring and advising these students about the value of participation. Because first-generation students enter higher education with limited knowledge of the college environment, practitioners may consider creating such activities upon entry, and supporting participation throughout college years.

In addition to creating opportunities around engaging academics, interacting with faculty, cultivating belonging, studying, interacting with diverse people, and developing a growth mindset, higher education practitioners could also create spaces on campus that support these college experiences for first-generation students. For example, counter-spaces could provide students of color physical spaces where they can network with campus community members and discuss their experiences with culture and integration in college (see Robertson et al., 2016; Solorzano, et al., 2000; Yosso et al., 2009). Counter spaces could provide a 
supportive structure that makes engaging college experiences easier and more relevant for these students. Likewise, such spaces could also benefit faculty members and students who do not identify as persons of color in shaping their understanding about the challenges students of color encounter in college.

Similarly, higher education practitioners could also review policies and practices on campus to ensure systems and processes are egalitarian so that first-generation students feel encouraged and welcomed to participate regardless of racial/ethnic identities. The antithesis of egalitarian environments are those that manufacture architectures supporting particular groups, namely White students, while disenfranchising students from other racial/ethnic backgrounds (see Collins \& Jun, 2017). Furthermore, such architectures may obviously, or surreptitiously, promote racism in ways not directly related to race (see Bonilla-Silva; 2018). Non-egalitarian environments are toxic for a racially/ethnically diverse population of first-generation college students learning to navigate a largely unfamiliar college environment, and undermine the significance of college experiences, especially in terms of cognitive outcomes.

\section{Conclusion}

The purpose of this study was to evaluate how select college experiences affect college outcomes among racial/ethnic populations of first-generation students. Multiple regression analysis showed that college experiences have varying effects on cognitive outcomes among first-generation subpopulations. Academic engagement was most important for Black students, while faculty interactions were most important for Asian students. Habits of mind and pluralistic orientation were most important for Hispanic students, while investing more time studying/homework and sense of belonging were most important for White students. Collectively, these findings suggest that patterns of racial/ethnic subpopulations of first-generation students differ in college, especially in terms of developing and refining cognitive outcomes. Researchers and practitioners can utilize the results of this study to create college experiences that promote success for racial/ethnic subpopulations of first-generation students in transition to largely unfamiliar college environments.

\section{References}

ACT. (2014a). The condition of college and career readiness: First-generation students. Council

for Opportunity in Education.

ACT. (2014b). The condition of college and career readiness: National. Council for Opportunity in Education.

ACT. (2015). The condition of college and career readiness: Students from low-income families. Council for Opportunity in Education.

ACT. (2016). The condition of college and career readiness: National.

ACT. (2017). The condition of college and career readiness: National. 
Alsalam, N. \& Rogers, G. T. (Eds.). (1990). The Condition of Education 1990 Volume 2: Postsecondary Education (NCES 90-684). U.S. Department of Education, National Center for Education Statistics. Washington, DC.

Aronson, J., \& Inzlicht, M. (2004). The ups and downs of attributional ambiguity: Stereotype vulnerability and the academic self-knowledge of African-American students. Psychological Science, 15(12), 829-836. https://doi.org/10.1111/j.0956-7976.2004.00763.x

Association of American Colleges and Universities. (2007). College learning for the new global century: A report from the National Leadership Council for liberal education and America's promise. Washington, DC: American Association of Colleges and Universities.

Astin, A. W. (1970). The methodology of research on college impact, part one. Sociology of Education, 43(3), 223-254. https://doi.org/10.2307/2112065

Astin, A. W. (1973). Measurement and determinants of the outputs of higher education. In L. C. Solmon and P. J. Taubman (Eds.). Does college matter? Some evidence on the impacts of higher education (pp. 107-127). New York, NY: Academic Press.

Astin, A. W. (1984). Student involvement: A developmental theory for higher education. Journal of College Student Personnel, 25(4), 297-308.

Astin, A. W. (1993a). Assessment for excellence: The philosophy and practice of assessment and evaluation in higher education. Phoenix, AZ: The Oryx Press.

Astin, A. W. (1993b). What matters in college? Four critical years revisited. San Francisco, CA: Jossey-Bass.

Baxter Magolda, M. B. (2001). Making their own way: Narratives for transforming higher education to promote self-development. Sterling, VA: Stylus.

Belenky, M. F., Clinchy, B. M., Goldberger, N. R., \& Tarule, J. M. (1997). Woman's ways of knowing: The development of self, voice, and mind. New York, NY: Basic books.

Billson, J. M., \& Terry, M. B. (1982). In search of the silken purse: Factors in attrition among first-generation students. Revision of paper presented at the Association of American Colleges, Denver, CO, January 1981.

Blackwell, E., \& Pinder, P. J. (2014). What are the motivational factors of first-generation minority college students who overcome their family histories to pursue higher education? College Student Journal, 48(1), 45-56.

Bonilla-Silva, E. (2018). Racism without racists. Lanham, MD: Rowman \& Littlefield.

Bowman, N. A. (2009). College diversity courses and cognitive development among students from privileged and marginalized groups. Journal of Diversity in Higher Education, 2(3), 182-194. https://doi.org/10.1037/a0016639

Bowman, N. A. (2010). Assessing learning and development among diverse college students. New Directions for Institutional Research, 145, 53-71. https://doi.org/10.1002/ir.322 


\section{$\triangle$ Macrothink}

Journal of Studies in Education

ISSN 2162-6952

2020, Vol. 10, No. 1

Bowman, N. A. (2013). How much diversity is enough? The curvilinear relationship between college diversity interactions and first-year student outcomes. Research in Higher Education, 54(8), 874-894. https://doi.org/10.1007/s11162-013-9300-0

Bowman, N. A., \& Seifert, T. A. (2011). Can college students accurately assess what affects their learning and development? Journal of College Student Development, 52(3), 270-290. https://doi.org/10.3102/0013189X10397630

Bui, K. V. T. (2002). First-generation college students at a four-year university: Background characteristics, reasons for pursuing higher education, and first-year experiences. College Student Journal, 36(1), 3-11.

Chen, X. (2005). First generation students in postsecondary education: A look at their college transcripts (NCES 2005-171). U.S. Department of Education, National Center for Education Statistics. Washington, DC: U.S. Government Printing Office.

Chen, X. (2013). STEM Attrition: College Students' Paths Into and Out of STEM Fields (NCES 2014-001). National Center for Education Statistics, Institute of Education Sciences, U.S. Department of Education. Washington, DC.

Coffman, S. (2011). A social constructionist view of issues confronting first-generation college students. New Directions for Teaching and Learning, 2011(127), 81-90. https://doi.org/10.1002/tl.459

Collins, C. S., \& Jun, A. (2017). White out: Understanding White privilege and dominance in the modern age. New York, NY: Peter Lang Publishing, Inc. https://doi.org/10.3726/b10660

DeAngelo, L., Franke, R., Hurtado, S., Pryor, J. H., \& Tran, S. (2011). Completing college: Assessing graduation rates at four-year institutions. Los Angeles: Higher Education Research Institute, UCLA.

Douglass, J. A., Thomson, G., \& Zhao, C. (2012). The learning outcomes race: The value of self-reported gains in large research universities. Higher Education, 64, 317-335. https://doi.org/10.1007/s10734-011-9496-X

Edens, D., Dy, H., Dalske, J., \& Strain, C. (2105). Cognitive skills development among transfer college students: An analysis by student gender and race. Journal of Education and Training 2(2), 117-135. https://doi.org/10.5296/jet.v2i2.7227

Engle, J., \& Tinto, V. (2008). Moving beyond access: College success for low-income first-generation students. The Pell Institute for the Study of Opportunity in Higher Education.

Filkins, J. W., \& Doyle, S. K. (2002). First-generation and low-income students: Using the NSSE data to study effective education practices and students' self-reported gains. Paper presented at the annual forum for the Association for Institutional Research, Toronto, Ontario, Canada. 
Fischer, M. J. (2007). Settling into campus life: Differences by race/ethnicity in college involvement and outcomes. The Journal of Higher Education, 78(2), 125-161. https://doi.org/10.1353/jhe.2007.0009

Flowers, L. A., \& Pascarella, E. T. (2003). Cognitive effects of college: Differences between African American and Caucasian Students. Research in Higher Education, 44(1), 21-49. https://doi.org/10.1023/A:1021313511802

Giancarlo, C. A, \& Facione, P. A. (2001). A look across four years at the disposition toward critical thinking among undergraduate students. The Journal of General Education, 50(1), 29-55. https://doi.org/10.1353/jge.2001.0004

Gonyea, R. M. (2005). Self-reported data in institutional research: Review and recommendations. New directions for Institutional Research, 127, 73-89. https://doi.org/10.1002/ir.156

Grodsky, E., Warren, J., \& Felts, E. (2008). Testing and social stratification in American education. Annual Review of Sociology, 34, 385-404. https://doi.org/10.1146/annurev.soc.34.040507.134711

Haller, A. O., \& Portes, A. (1973). Status attainment processes. Sociology of Education, 46(1), 51-91. https://doi.org/10.2307/2112205

Hernandez, J. C. (2000). Understanding the retention of Latino college students. Journal of College Student Development, 41(6), 575-588.

Hussar, W.J., and Bailey, T.M. (2013). Projections of Education Statistics to 2022 (NCES 2014-051). U.S. Department of Education, National Center for Education Statistics. Washington, DC: U.S. Government Printing Office.

Ishitani, T. T. (2006). Studying attrition and degree completion behavior among first-generation college students in the United States. The Journal of Higher Education, 77(5), 861-885. https://doi.org/10.1353/jhe.2006.0042

Kena, G., Hussar W., McFarland J., de Brey C., Musu-Gillette, L., Wang, X., Zhang, J., Rathbun, A., Wilkinson-Flicker, S., Diliberti M., Barmer, A., Bullock Mann, F., and Dunlop Velez, E. (2016). The Condition of Education 2016 (NCES 2016-144). U.S. Department of Education, National Center for Education Statistics. Washington, DC.

Kim, Y. K., Edens, D., Iorio, M. F., Curtis, C. J., \& Romero, E. (2015). Cognitive skills development among international students at research universities in the United States. Journal of International Students, 5(4), 526-540.

Kim, Y. K., Rennick, L. A., \& Franco, M. A. (2014). Latino college students at highly selective institutions: A comparison of their college experiences and outcomes to other racial/ethnic groups. Journal of Hispanic Higher Education, 13(4), 245-268. http://dx.doi.org/10.1177/1538192714532815 
Kim, Y. K., \& Sax, L. J. (2007). Different patterns of student-faculty interaction in research universities: An analysis by student gender, race, SES, and first-generation status. Research and Occasional Paper Series: CSHE.10.07. University of California, Berkeley.

Kim, Y. K., \& Sax, L. J. (2009). Student-faculty interaction in research universities: Differences by student gender, race, social class, and first-generation status. Research in Higher Education, 50(5), 437-459. https://doi.org/10.1007/s11162-009-9127-X

Kitchener, K. S., \& King, P. M. (1981). Reflective judgment: Concepts of justification and their relationship to age and education. Journal of Applied Developmental Psychology, 2, 89-116. http://dx.doi.org/10.1016/0193-3973(81)90032-0

Kugelmass, H. \& Ready, D. D. (2011). Racial/ethnic disparities in collegiate cognitive gains: A multilevel analysis of institutional influences on learning and its equitable distribution. Research in Higher Education 52, 323-348. https://doi.org/10.1007/s11162-010-9200-5

Kuh, G. D., Hayek, J. C., Carini, R.M., Ouimet, J. A., Gonyea, R. M., \& Kennedy, J. (2001). NSSE Technical and Norms Report. Bloomington, IN: Indiana University Center for Postsecondary Research and Planning.

Lundberg, C. A., \& Schreiner, L. A. (2004). Quality and frequency of faculty-student interaction as predictors of learning: An analysis by student race/ethnicity. Journal of College Student Development, 45(5), 549-565. https://doi.org/10.1353/csd.2004.0061

Mayhew, M. J., Rockenbach, A. N., Bowman, N. A., Seifert, T. A., Wolniak, G. C., Pascarella, E. T., \& Terenzini, P. T. (2016). How college affects students: $21^{\text {st }}$ century evidence that higher education works (Vol 3). San Francisco, CA: Jossey-Bass Publishers.

McFarland, J., Hussar, B., de Brey, C., Snyder, T., Wang, X., Wilkinson-Flicker, S., Gebrekristos, S., Zhang, J., Rathbun, A., Barmer, A., Bullock Mann, F., and Hinz, S. (2017). The Condition of Education 2017 (NCES 2017-144). U.S. Department of Education. Washington, DC: National Center for Education Statistics.

Mertler, C. A., \& Vannatta, R. A. (2010). Advanced and multivariate statistical methods $\left(4^{\text {th }}\right.$ ed.). Glendale, CA: Pyrczak Publishing.

Musu-Gillette, L., Robinson, J., McFarland, J., KewalRamani, A., Zhang, A., and Wilkinson-Flicker, S. (2016). Status and Trends in the Education of Racial and Ethnic Groups 2016 (NCES 2016-007). U.S. Department of Education, National Center for Education Statistics. Washington, DC.

Nelson Laird, T. F., Seifert, T. A., Pascarella, E. T., Mayhew, M. J., \& Blaich, C. F. (2014). Deeply affecting first-year students' thinking: Deep approaches to learning and three dimensions of cognitive development. The Journal of Higher Education, 85(3), 402-432. https://doi.org/10.1353/jhe.2014.0017

Noll, E., Reichlin, L., \& Gault, B. (2017). College students with children: National and regional profiles. Institute for Women's Policy Research. Retrieved on June 6, 2019 from https://iwpr.org/ 


\section{Mll Macrothink}

Journal of Studies in Education

ISSN 2162-6952 2020, Vol. 10, No. 1

Nord, C., Roey, S., Perkins, R., Lyons, M., Lemanski, N., Brown, J., \& Schuknecht, J. (2011). The Nation's Report Card: America's High School Graduates (NCES 2011-462). U.S. Department of Education, National Center for Education Statistics. Washington, DC: U.S. Government Printing Office.

Pace, C. R. (1979). Measuring college outcomes: Fifty years of findings and recommendations for the future. San Francisco, CA: Jossey-Bass Publishers.

Pace, R. C. \& Others. (1985). The credibility of student self-reports. National Institute of Education. Washington, DC.

Padgett, R. D., Johnson, M. P., \& Pascarella, E. T. (2012). First-generation undergraduate students and the impacts of the first year of college: Additional evidence. Journal of College Student Development 53(2), 243-266. https://doi.org/10.1353/csd.2012.0032

Park, J. J. (2013). When diversity drops: Race, religion, and affirmative action in higher education. New Brunswick, NJ: Rutgers University Press.

Pascarella, E. T., Pierson, C. T., Wolniak, G. C., \& Terenzini, P. T. (2004). First-Generation College Students: Additional evidence on college experiences and outcomes. Journal of Higher Education, 75(3), 249-284. https://doi.org/10.1353/jhe.2004.0016

Pascarella, E. T., \& Terenzini, P. T. (1991). How college affects students: Findings and insights from twenty years of research. San Francisco, CA: Jossey-Bass Publishers.

Pascarella, E. T., \& Terenzini, P. T. (2005). How college affects students: A third decade of Research (Vol. 2). San Francisco, CA: Jossey-Bass.

Perry, W. G. (1999). Forms of ethical and intellectual development in the college years: A scheme. San Francisco, CA: Jossey-Bass Publishers.

Piaget, J. (1967). The psychology of intelligence. London: Routlage \& Kegan Paul Ltd.

Pike, G. R. (1996). Limitations of using students' self-reports of academic development as proxies for traditional achievement measures. Research in Higher Education, 37(1), 89-114. https://doi.org/10.1007/BF01680043

Pike, G. R., Kuh, G. D., McCormick, A. C., Ethington, C. A., \& Smart, J. C. (2011). If and when money matters: Direct and indirect relationships between expenditures and student learning. Paper presented at the annual meeting of the Association for the Study of Higher Education, Louisville, KY.

Prospero, M., Russell, A. C., \& Vohra-Gupta, S. (2012). Effects of motivation on educational attainment: Ethnic and developmental differences among first-generation students. Journal of Hispanic Higher Education, 11, 100-119. https://doi.org/10.1177/1538192711435556

Robertson, R. V., Bravo, A., \& Chaney, C. (2016). Racism and the experiences of Latina/o college students at a PWI (Predominantly White Institution). Critical Sociology, 42(4-5), 715-735. https://doi.org/10.1177/0896920514532664 


\section{Macrothink}

Journal of Studies in Education

ISSN 2162-6952

2020, Vol. 10, No. 1

Roska, J., \& Arum, R. (2015). Inequality in skill development on college campuses. Research in Social Stratification and Mobility, 39, 18-31. https://doi.org/10.1016/j.rssm.2014.09.001

Roksa, J., Trolian, T.L., Pascarella, E.T. Kilgo, C.A., Blaich, C., \& Wise, K.S. (2017). Racial inequity in critical thinking skills: The role of academic and diversity experiences. Research in Higher Education, 58(2), 119-140. https://doi.org/10.1007/s11162-016-9423-1

Saenz, V. B., Hurtado, S., Barrera, D., Wolf, D., \& Yeung, F. (2007). First in my family: A profile of first-generation college students at four-year institutions since 1971. Los Angeles: Higher Education Research Institute, UCLA.

Shim, W. \& Walczak, K. (2012). The impact of faculty teaching practices on the development of students' critical thinking skills. International Journal of Teaching and Learning in Higher Education, 24(1), 16-30.

Snyder, T.D., de Brey, C., and Dillow, S.A. (2019). Digest of Education Statistics 2017 (NCES 2018-070). National Center for Education Statistics, Institute of Education Sciences, U.S. Department of Education. Washington, DC.

Snyder, T.D., \& Dillow, S.A. (2012). Digest of Education Statistics 2011 (NCES 2012-001). National Center for Education Statistics, Institute of Education Sciences, U.S. Department of Education. Washington, DC.

Solorzano, D., Ceja, M., \& Yosso, T. (2000). Critical race theory, racial microaggressions, and campus racial climate: The experiences of African American college students. Journal of Negro Education, 69(1-2), 60-73.

Steele, C. M., \& Aronson, J. (1995). Stereotype threat and the intellectual test performance of African-Americans. Journal of Personality and Social Psychology, 69, 797-811. https://doi.org/10.1037/0022-3514.69.5.797

Tabachnick, B. G, \& Fidell, L. S. (2013). Using multivariate statistics ( $6^{\text {th }}$ ed). Boston, MA: Pearson.

Terenzini, P. T., Springer, L., Yaeger, P. M., Pascarella, E. T., \& Nora, A. (1996). First-generation college students: Characteristics, experiences, and cognitive development. Research in Higher Education 37(1), 1-22. https://doi.org/10.1007/BF01680039

Thorndike, E.L. (1920). A constant error on psychological rating. Journal of Applied Psychology, IV, 25-29. https://doi.org/10.1037/h0071663

Tinto, V. (1993). Leaving college ( $2^{\text {nd }}$ ed.). Chicago, IL: The University of Chicago Press.

Umbach, P. D. \& Kuh, G. D. (2006). Student experiences with diversity at liberal arts colleges: Another claim for distinctiveness. The Journal of Higher Education, 77(1), 169-192. https://doi.org/10.1353/jhe.2006.0008

U. S. Department of Education, National Center for Education Statistics. (2011). Trends in attainment among student populations at increases risk of noncompletion: Selected years, 1989-90 to 2008-09 (NCES 2012-254). 


\section{Macrothink}

Journal of Studies in Education

ISSN 2162-6952

U. S. Department of Education, National Center for Education Statistics. (2014). Web Tables-Profile of undergraduate students: 2011-2012 (NCES 2015-167).

U. S. Department of Labor, Bureau of Labor Statistics (2018). Unemployment rates and earnings by educational attainment. Retrieved on February 6, 2019 from https://www.bls.gov/emp/tables/unemployment-earnings-education.htm

Watkins, D. (2000). Learning and teaching: a cross-cultural perspective. School Leadership \& Management, 20(2), 161-173. https://doi.org/10.1080/13632430050011407

Whitmire, E. (1996). Undergraduate students' development of critical thinking skills: An institutional and disciplinary analysis and comparison with academic library use and other measures. Paper presented at the annual meeting of the Association for the Study of Higher Education.

Whitten, D., \& Brahmasrene, T. (2011). Predictors of critical thinking skills of incoming business students. Academy of Educational Leadership Journal, 15(1), 1-13.

Yosso, T. J., Smith, W. A., Ceja, M., \& Solorzano, D. G. (2009). Critical race theory, racial microaggressions, and campus racial climate for Latina/o undergraduates. Harvard Educational Review, 79(4), 659-691. https://doi.org/10.17763/haer.79.4.m6867014157m7071 